\title{
Effect of Fennel (Foeniculum Vulgare Mill.) Used as a Feed Additive on The Egg Quality of Laying Hens Under Heat Stress
}

http://dx.doi.org/10.1590/1516-635x1702199-208

\section{-Author(s)}

Gharaghani $\mathrm{H}^{\prime}$

Shariatmadari Fi"

Torshizi MA"

Department of Animal Science, Faculty of Agriculture, Tarbiat Modares University, Tehran, Iran.

" Department of Poultry Science, Faculty of Agriculture, Tarbiat Modares University, Tehran, Iran.

\section{Mail Address}

Corresponding author e-mail address

Farid shariatmadari

Tel: $+98+2144580500$

Fax: +98+2144196524

E-mail: shariatf@modares.ac.ir

\section{Eeywords}

Fennel, heat stress, laying hens, antioxidant, feed.

\section{ABSTRACT}

In this study, one hundred and twenty 40-wk-old White Leghorn laying hens were submitted to two different thermal conditions $\left(24^{\circ}\right.$ C vs. $34^{\circ} \mathrm{C}$ ) and were fed three levels $(0,10$, or and $20 \mathrm{~g} / \mathrm{kg}$ of diet) of fennel fruits (Foeniculum vulgare Mill.) as a feed additive in. This study was carried out according to a factorial design consisting of two temperatures and three fennel levels with five 5 replicates each $(n=$ $2 \times 3 \times 5$ ). Performance, egg production, egg quality, and oxidative product levels (malondialdehyde, MDA, and carbonyl) in the eggs were measured before and after heat exposure. The results showed that the tested temperatures did not affect egg production ( $p>0.05)$, but the production of eggs with broken shell and feed intake were affected by heat stress $(p<0.05)$. The different temperatures also affected egg quality $(p<0.05)$, reducing egg weight $(E W)$, eggshell thickness $(E S T)$, eggshell strength (ESS), Haugh units $(\mathrm{HU})$, albumen height $(\mathrm{AH})$, and albumen weight (AW). At the high environmental temperature, MDA and carbonyl egg contents increased $(p<0.05)$, while fennel consumption reduced the values of both parameters. Heat stress had no effect on yolk cholesterol levels ( $p>0.05)$, but increased yolk triglyceride levels. Hens that consumed fennel presented lower yolk cholesterol and triglyceride levels $(p<0.05)$. In general, fennel fruit influenced egg yolk cholesterol and triglyceride contents, and because of its antioxidant properties, it may alleviate the adverse effects of heat stress on laying hens.

\section{INTRODUCTION}

Heat stress causes serious physiological dysfunction that may result in a decline in animal performance (Gous \& Morris, 2005). High temperatures have been proposed to be responsible for stimulating free radical production both in the animal body and animal products (Yahav, 2009). In summer, high environmental temperatures can be detrimental to laying hens, not only because of it may increase mortality, but also because of the reduction in the number and in the quality of the eggs produced during heat stress. Studies on alleviation of heat stress have focused on costly management adjustments and genetic improvement for heat tolerance. Relative to the formation of free radicals in the body and reproductive system of laying hens under heat stress conditions (Gous \& Morris, 2005), it seems that the use of antioxidants may help the hens by reducing the harmful effect of heat stress.

During heat stress, birds pant to lose heat as water vapor. The increase in respiration rate reduces blood partial pressure of $\mathrm{CO}_{2}\left(\mathrm{PCO}_{2}\right)$ and bicarbonate $\left(\mathrm{HCO}_{3}\right)$, and increases blood $\mathrm{pH}$, resulting in respiratory alkalosis (Sahin et al.,2013), which directly influences the formation of the eggshell (Odom, 1986). 
Several researchers have reported the possibility of growth-promoting and antioxidant effects of some traditional medicinal herbs (Park \& Yoo, 1999; Liu et al., 2006; Sahin et al., 2013). These medicinal herbs are considered natural products, and therefore consumers may willingly allow them to be included in livestock feeds. Wood \& Enser (1997) recommended the use of dietary antioxidants to reduce lipid peroxidation in animal feeds, consequently preserving the quality of animal products. Recent research on antioxidants has focused on naturally occurring molecules to reduce consumers' concerns on the safety and toxicity of the synthetic counterparts. In this respect, herbs and their extracts with antioxidant capacity are being tested to evaluate if they can improve animal performance and the quality and shelf life of meat products (Lopez-Bote et al., 1998; Vichi et al., 2001; Simitzis et al., 2008).

Fennel (Foeniculum vulgare mil.) is a plant from Apiaceae family, known and used by humans since ancient times. It is cultivated in the Mediterranean region because of its flavor, and it is used in traditional medicine and as a spice. Interests in natural products rather than synthetic agents have focused attention on plants as a source of flavoring compounds (Yaylayan, 1991). Fennel is an aromatic edible plant whose fruit is used for savory formulations, sauces, liqueurs, confectionery, etc. (Guilled \& Manzanons, 1996).

Comprehensive investigations on fennel leaves and fruits showed that its essential oil has very strong antioxidant, antimicrobial, and hepatoprotective activity (Ruberto et al., 2000; Ozbek et al., 2003). The chemical composition of the volatile oil fractions was well described by Badoc et al., (1994); Piccaglia and Marotti (2001) and Damianova et al., (2004).

In the past decades, research efforts focused on reducing egg cholesterol content by genetic selection or alteration of the diet of laying hens with various nutrients, natural products, nonnutritive factors, or pharmacological agents (Elkin, 2007). However, these efforts have demonstrated that it is extremely difficult to reduce egg cholesterol by ordinary means. It is known that dietary manipulations to reduce yolk cholesterol also decrease egg size and production (Kim et al., 2004). There are evidences that some medicinal plants such as black cumin significantly reduce plasma and egg yolk cholesterol and triglycerides (Akhtar et al., 2003).
The aim of the present study was to determine the effect of the fennel fruit used as a feed additive on the performance and egg quality of laying hens submitted to heat stress.

\section{MATERIALS AND METHODS}

\section{Hens and experimental design}

One hundred and twenty 40-week-old White Leghorn laying hens were housed in group cages (four birds per cage) under ambient temperature and were provided $16 \mathrm{~h}$ of light per day. Hens were fed a commercial layer feed (155 g protein per kg of diet), according to the genetic company management manual (Table 1). Feed and water were supplied ad libitum throughout the pre-experimental and experimental periods. Egg production was recorded daily and body weight and feed intake measured weekly. After two weeks of data recording, hens were reallocated in the cages in order to obtain the same body weight and egg production in each cage.

During the experimental period, birds received three levels of fennel $(0,10$, or $20 \mathrm{~g} / \mathrm{kg})$ in the diet for one month (30 days). Egg production and number of eggs with broken shells were recorded daily and body weight and feed intake measured weekly. A completely randomized experimental design, with three treatments with 10 replicates per treatment of four layers per replicate $(n=3 \times 10)$ was applied.

On day 31, hens were divided in two groups and one was transferred into another environmentallycontrolled room. Birds in the new room were exposed

Table1 - Composition and calculated nutrient content of basal diet.

\begin{tabular}{lccc}
\hline alngredients (g/kg) & & \multicolumn{2}{c}{ calculated nutrient content (as-fed basis; g/kg) } \\
\hline Corn & 667.99 & ME (MJ/kg) & 12.13 \\
\hline Soybean Meal (42\%) & 197.57 & Crude protein & 155.00 \\
\hline Fat & 15.15 & $\mathrm{Ca}$ & 40.30 \\
\hline Dical. Phos. & 11.22 & Available P & 3.40 \\
\hline $\mathrm{CaCO}_{3}$ & 97.97 & $\mathrm{Na}$ & 1.90 \\
\hline Common Salt & 4.41 & Lys & 7.90 \\
\hline Methionine & 0.68 & Met & 3.50 \\
\hline${ }^{b}$ Vitamin premix & 2.50 & Met + Cys & 5.90 \\
\hline${ }^{c}$ Mineral premix & 2.50 & & \\
\hline
\end{tabular}

aNutrient composition of feed ingredient calculated according to NRC (1994).

'Premix provided the following per kilogram of diet: $4.8 \mathrm{mg}$ of retinol acetate, $100 \mu \mathrm{g}$ of cholecalciferol, $20 \mathrm{mg}$ of DL- $囚$-tocopheryl acetate, $4.5 \mathrm{mg}$ menadione sodium bisulphate, $4.1 \mathrm{mg}$ thiamine hydrochloride, $9.5 \mathrm{mg}$ of riboflavin, $15 \mathrm{mg}$ of calcium-D-pantothenate, $45 \mathrm{mg}$ of nicotinic acid, $9 \mathrm{mg}$ of pyridoxine hydrochloride, $2.2 \mathrm{mg}$ of folic acid, $0.25 \mathrm{mg}$ biotin, $12 \mathrm{mg}$ ascorbic acid and $550 \mathrm{mg}$ of choline chloride.

cPremix provided the following per kilogram of diet: $80 \mathrm{mg}$ of $\mathrm{Zn}, 30 \mathrm{mg}$ of Fe, $100 \mathrm{mg}$ of $\mathrm{Mn}, 20 \mathrm{mg}$ of $\mathrm{Cu}, 0.4 \mathrm{mg}$ of $\mathrm{Co}, 1.2 \mathrm{mg}$ of I, $0.4 \mathrm{mg}$ of Se. 
to continuous high environmental temperature $\left(34^{\circ} \mathrm{C}\right.$ $\pm 1^{\circ} \mathrm{C}$ ) and the other group was maintained under thermoneutral conditions $\left(24^{\circ} \mathrm{C} \pm 1^{\circ} \mathrm{C}\right)$ during the whole day. The experimental design applied for this part of study was a factorial design with two environmental temperatures $\left(34^{\circ} \mathrm{C}\right.$ vs. $24^{\circ} \mathrm{C}$ ) and three dietary levels of fennel $(0,10$, or $20 \mathrm{~g} / \mathrm{kg})$, with five replicates per treatment and four birds per replicate $(n=2 \times 3 \times 5)$.

Egg quality parameters were measured before heat exposure (day 30) and one month after heat exposure (day 60).

\section{Extraction and analysis of volatile compounds}

Newly-harvested fennel fruits were obtained from the Horticultural Science Department of Tarbiat Modares University, Tehran, Iran. One g fennel fruit was ground into a fine powder in a mill and extracted in 10 mLhexane on a rotor shaker for $1 \mathrm{~h}$ at room temperature. The extract solution was removed and the procedure was repeated twice, each with an additional $5 \mathrm{~mL}$ hexanefor $30 \mathrm{~min}$. The extracted solution was filtered through adouble layer of filter paper (Whatman, No. 1; Whatman Inc., Clifton, NJ, USA) and with sodium sulfate to remove excess water (Barazani et al., 1999). Average amount of volatile compounds for fennel fruit was 0.039 .

One microliter of the hexane extract was injected in the gas chromatography-mass spectrometry (GCMS) apparatus for the analysis the volatile compounds of fennel (Barazani et al., 1999). The quantitative analyses were performed by using ethylmyristate (10$40 \mathrm{mg}$ ) as an internal standard. The partitioning of the main volatile substrate in $1 \mathrm{~g}$ of fennel fruit was: 25.0 $\mathrm{ng}$ anethole, $7.5 \mathrm{ng}$ fenchone and $2.5 \mathrm{ng}$ estragole.

\section{Egg Quality Measurements}

Freshly-laid eggs were collected daily to record production. Egg quality measurements were taken twice during the experimental period: before (day 30) and after heat exposure (day 60). For each examination, two eggs were randomly selected from each replicate to measure internal and external characteristics. Time interval between egg laying and measurements was less than $24 \mathrm{~h}$. The eggs were stored at $4^{\circ} \mathrm{C}$ temperature before measuring egg quality criteria.

Eggs were tested on the Eggshell Force Gauge (Robotmation Co. Ltd., Tokyo, Japan) to determine eggshell strength (ESS; Er et al., 2007). Egg weight $(E W)$, albumen height $(\mathrm{AH})$, Haugh unit $(\mathrm{HU})$, and yolk color (YC) were measured using the Egg Multi Tester EMT-5200 (Robotmation Co. Ltd.; Asli et al., 2007).
Then the yolk and albumen were separated and weighed to determine yolk weight (YW) and albumen weight (AW). Eggshell was weighed with eggshell membranes giving eggshell weight (ESW). Eggshell thickness (EST) was measured at the blunt, equatorial, and sharp regions to obtain the average value (Van Den Brand et al., 2004).

\section{Thiobarbituric acid (TBA) determination}

Malondialdehyde (MDA), as a secondary oxidation product, was measured according to the TBA (thiobarbituricacid) method described by Botsoglou et al. (1994) using third derivative spectrophotometry with some modifications. A sample of fresh egg $(1.5 \mathrm{~g})$ was weighed into a $25 \mathrm{~mL}$ screw-capped centrifuge tube, and $5 \mathrm{~mL}$ of $0.8 \%$ butylated hydroxytoluene in hexane was immediately added. Just before homogenization, $8 \mathrm{~mL}$ of $5 \%$ aqueous trichloroacetic acid (TCA) was added to the tube. The mixture was vortexed for $40 \mathrm{~s}$; the top hexane layer was discarded, and the bottom aqueous layer was filtered through Whatman No. 1 filter paper. The volume was increased to $10 \mathrm{~mL}$ with TCA. After filtration, a 3-mL aliquot was transferred to another tube and mixed with $2 \mathrm{~mL}$ of $0.8 \%$ TBA. The mixture was incubated for exactly $30 \mathrm{~min}$ at $70^{\circ} \mathrm{C}$ in a water bath under gentle agitation and then cooled in an ice bath for $7 \mathrm{~min}$. The tube then was tempered for $45 \mathrm{~min}$ at room temperature and the reaction mixture was used for third-order derivative spectrophotometry. The height of the third-order derivative peak that appeared at approximately $521.5 \mathrm{~nm}$ was used for calculation of the MDA concentration in the evaluated extract on the basis of slope and intercept data of the computed least-squares fit of a freshly prepared standard curve. Tetraethoxypropane was used as MDA precursor in the standard curve (Galobart et al., 2001).

\section{Protein Oxidation in Egg White}

The concentration of protein carbonyls in egg white was measured to estimate protein oxidation using modified method of Mercier et al. (2001). One milliliter of egg white was diluted with $19 \mathrm{~mL}$ of deionized distilled water (DDW) and then homogenized using a polytron (type PT 10/35, Brinkman Instruments, Inc., Westbury, NY, USA) for $5 \mathrm{~s}$ at high speed. One milliliter of diluted egg white was divided into 2 aliquots of 0.5 $\mathrm{mL}$. Proteins in both aliquots were precipitated with $0.5 \mathrm{~mL}$ of $20 \%$ trichloroacetic acid (TCA). Both aliquots were centrifuged at $3000 \times \mathrm{g}$ for $10 \mathrm{~min}$, and then supernatants were discarded. The pellet of one aliquot was treated with $1 \mathrm{~mL}$ of $2 \mathrm{~N} \mathrm{HCl}$ and the other with 1 $\mathrm{mL}$ of $0.2 \%$ 2,4-dinitrophenylhydrazine in $2 \mathrm{NHCl}$ (wt/ 
vol). The samples were placed at room temperature for $1 \mathrm{~h}$ with regular stirring, precipitated with $1 \mathrm{~mL}$ of $20 \%$ $\mathrm{TCA}$, and then centrifuged at $3000 \times \mathrm{g}$ for $10 \mathrm{~min}$. The pellets were collected and washed twice with ethanol/ ethyl acetate (1:1) dissolved in $2 \mathrm{~mL}$ of 6 Mguanidine$\mathrm{HCl}$ in $20 \mathrm{mM}$ sodiumphosphate buffer ( $\mathrm{pH} \mathrm{6.5),} \mathrm{and}$ then centrifuged at $3000 \times \mathrm{g}$ for $10 \mathrm{~min}$ to remove insoluble debris. The absorbance of supernatants from $\mathrm{HCl}$-treated and 2,4-dinitrophenylhydrazine-treated samples were taken to obtain protein carbonyl content using the molar extinction coefficient of $21000 \mathrm{~m} /$ $\mathrm{cm}$ for protein hydrazone. Protein concentration was determined at $280 \mathrm{~nm}$ with $\mathrm{HCl}$-treated samples, using BSA in the $6 \mathrm{M}$ guanidine solution as a standard.

\section{Cholesterol and triglyceride analysis}

The cholesterol and triglycerides contents of the egg yolks were determined according to the methods described by Hammad et al. (1996) and Kaya et al. (2001). Yolks were separated from albumen, and $0.1 \mathrm{~g}$ samples of yolks was weighed in a tube. Yolk lipids were extracted with isopropanol $(4 \mathrm{~mL})$, vortexed for 2 to 3 min, and then centrifuged at $907 \times \mathrm{g}$ for $10 \mathrm{~min}$. The yolk cholesterol and triglyceride concentration $(\mathrm{mg} / \mathrm{g}$ of egg yolk) was determined in the filtered samples by ultraviolet spectrophotometer using commercial kits (Pars Azmoon, Tehran, Iran) and calculated by the method of Boehringer Mannheim GmbH Biochemica (1989).

\section{Statistical analysis}

Because before heat stress all birds were submitted only to the fennel treatment, collected data were submitted to analysis of variance according to a completely randomized design $(n=3 \times 10)$. After the birds experienced two different temperatures (in addition to the fennel treatment), data were submitted to analysis of variance according to a factorial design $(2 \times 3)$. Basic statistics and analysis of variance were performed to test if there were significant differences among treatments. The differences among means were significant, means were further analyzed using Duncan's multiple range tests. Data were analyzed using PROC GLM (SAS Institute, Cary, NC). In all cases, P-values $\leq 0.05$ were considered significant.

\section{RESULTS AND DISCUSSION}

The exposure of birds to heat stress for one month (day 60) had no effect on layer performance. The body weight (BW) of hens was not different at the start of the experiment (Table 2). In addition, BW of birds after one month consumption of fennel (day 30) and after one month exposure to heat stress (day 60) did not change. The feed intake (FI) was not statically different among birds fed various levels of fennel inclusion, but heat stress reduced $(p<0.05)$ feed intake (day 31 60 ). All birds at the beginning of experiment (day 0 ) had equal egg production (EP). After one month of

Table 2 - Effect of heat stress and fennel consumption on performance and egg production of laying hens

\begin{tabular}{|c|c|c|c|c|c|c|c|c|c|c|c|}
\hline Treatment & BW $(g) d 0$ & $\begin{array}{c}\mathrm{BW}(\mathrm{g}) \\
\mathrm{d} 30\end{array}$ & $\begin{array}{c}\mathrm{BW}(\mathrm{g}) \\
\mathrm{d} 60\end{array}$ & $\begin{array}{l}\mathrm{a} F \mathrm{gl}(\mathrm{g}) \\
0-30 \mathrm{~d}\end{array}$ & $\begin{array}{c}{ }^{\mathrm{a} F I}(\mathrm{~g}) \\
30-60 \mathrm{~d}\end{array}$ & EP d0 & EP d30 & EP d60 & BEP dO & BEP d30 & BEP d60 \\
\hline \multicolumn{12}{|l|}{ Temperature } \\
\hline $24^{\circ} \mathrm{C}$ & & & 1576.00 & & $738.00^{x}$ & & & 0.87 & & & $0.03^{y}$ \\
\hline $34^{\circ} \mathrm{C}$ & & & 1549.00 & & $663.00^{y}$ & & & 0.83 & & & $0.14^{x}$ \\
\hline \multicolumn{12}{|c|}{ Fennel level ( $\mathrm{g} / \mathrm{kg}$ diet) } \\
\hline 0 & 1643.00 & 1633.00 & 1603.00 & 648.00 & 687.50 & 0.82 & 0.81 & 0.87 & 0.03 & 0.04 & $0.14^{x}$ \\
\hline 10 & 1586.00 & 1587.00 & 1561.00 & 653.00 & 732.00 & 0.90 & 0.77 & 0.83 & 0.02 & 0.03 & $0.07^{x y}$ \\
\hline 20 & 1614.00 & 1615.00 & 1525.00 & 755.00 & 682.50 & 0.90 & 0.91 & 0.85 & 0.03 & 0.03 & $0.05^{y}$ \\
\hline SE & 20.83 & 27.35 & 24.11 & 22.89 & 17.64 & 0.02 & 0.04 & 0.01 & 0.01 & 0.02 & 0.02 \\
\hline CV & 7.21 & 6.57 & 8.31 & 12.94 & 11.88 & 10.76 & 20.02 & 9.18 & 25.01 & 29.89 & 8.98 \\
\hline \multicolumn{12}{|l|}{$p$-value } \\
\hline Fennel & 0.566 & 0.665 & 0.429 & 0.927 & 0.366 & 0.109 & 0.087 & 0.602 & 0.998 & 0.988 & 0.068 \\
\hline Temperature & & & 0.577 & & 0.025 & & & 0.262 & & & 0.001 \\
\hline Interaction & & & 0.789 & & 0.510 & & & 0.113 & & & 0.047 \\
\hline
\end{tabular}

Means in the same column with different letter are significantly different $(p<0.05)$.

BW: body weight, FI: feed intake, EP: egg production, BEP: broken egg production, d: day.

a Feed intake values are average consumption for one week. 
fennel consumption, all birds presented lower egg production, but in those fed fennel, independently of level, this reduction was smaller. Heat stress increased $(p<0.05)$ the number of broken eggs, although it was lower when heat-stressed hens consumed fennel $(p<0.05)$. There was an interaction $(p<0.05)$ between environmental temperature and fennel consumption for the number of broken eggs, as shown in table 5 . Birds that did not consume fennel had the highest level of broken eggs (0.25) among the birds exposed to heat stress.

Before heat exposure, egg quality parameters, including EW, $\mathrm{AH}, \mathrm{HU}, \mathrm{YC}, \mathrm{ESS}, \mathrm{YW}, \mathrm{AW}$ and ESW, were not different (data are not presented). After one month of heat stress exposure, most of egg quality parameters were affected $(p<0.05)$ and got worse (Table 3), except for YW and ESW, which were not affected by heat stress. Both egg external and internal quality parameters were affected by heat stress. Among the birds exposed to heat stress, those that consumed fennel presented better egg quality. There was an interaction between temperature and fennel consumption for EST, ESS, and HU (Table 5). These observations show that fennel alleviated some of the harmful effects of heat stress on laying hens. It seems that the consumption of more than $10 \mathrm{~g}$ fennel/ $/ \mathrm{kg}$ diet does affect egg quality.
Data showed a high production of oxidative compounds in the eggs when hens were submitted. Both MDA and carbonyl egg contents were low when hens were maintained at ambient temperature (Table 4). The consumption of fennel under this condition had little effect on oxidative product content; however, under heat stress, when high levels of oxidative compounds are produced, the consumption of fennel significantly reduced these levels $(p<0.05)$.

Egg yolk cholesterol was not affected by heat stress, but triglyceride yolk content decreased when hens were under heat stress $(p<0.05)$. Regardless of environmental temperature, the inclusion of fennel in the diet reduced yolk cholesterol and triglyceride contents $(p<0.05)$. The results presented in Table 5 show that there was an interaction between temperature and fennel consumption level for triglyceride, MDA, and carbonyl egg contents.

\section{DISCUSSION}

According to Oktay et al. (2003), the antioxidant activity of fennel extract is comparable to that of synthetic antioxidants (in vitro) and the present study introduced fennel fruits as a natural antioxidant. On the other hand, there are many studies (Mashaly et al., 2004; Oguntunji \& Alabi, 2010) on the effects of heat stress effects on laying hens that indicate that, under

Table 3 - Egg quality after one month exposure to heat stress (day 60).

\begin{tabular}{|c|c|c|c|c|c|c|c|c|c|}
\hline Treatment & EW & EST & ESS & $Y C$ & $\mathrm{HU}$ & $\mathrm{AH}$ & YW & AW & ESW \\
\hline \multicolumn{10}{|l|}{ Temperature } \\
\hline $24^{\circ} \mathrm{C}$ & $61.16^{x}$ & $0.30^{x}$ & 2.66 & 5.86 & $85.59^{x}$ & $7.58^{x}$ & 16.80 & $39.06^{x}$ & 5.29 \\
\hline $34^{\circ} \mathrm{C}$ & $57.19^{y}$ & $0.26^{y}$ & 2.46 & 5.33 & $79.00^{y}$ & $6.46^{y}$ & 16.41 & $35.65^{y}$ & 5.13 \\
\hline \multicolumn{10}{|c|}{ Fennel level (g/kg diet) } \\
\hline 0 & 58.04 & $0.26^{y}$ & $2.32^{y}$ & 5.40 & $79.58^{y}$ & $6.53^{y}$ & 16.25 & 36.28 & 5.50 \\
\hline 10 & 59.14 & $0.28^{x}$ & $2.66^{x}$ & 5.60 & $82.73^{x y}$ & $7.02^{x y}$ & 16.76 & 37.23 & 5.15 \\
\hline 20 & 60.35 & $0.29^{x}$ & $2.71^{x}$ & 5.80 & $84.58^{x}$ & $7.51^{x}$ & 16.81 & 38.57 & 4.97 \\
\hline SE & 0.70 & $<0.01$ & 0.10 & 0.14 & 1.20 & 0.21 & 0.24 & 0.58 & 0.12 \\
\hline$C V$ & 4.44 & 8.20 & 13.88 & 13.24 & 5.93 & 12.11 & 8.92 & 5.36 & 13.34 \\
\hline \multicolumn{10}{|l|}{$p$-value } \\
\hline Fennel & 0.178 & 0.015 & 0.050 & 0.498 & 0.048 & 0.042 & 0.654 & 0.064 & 0.244 \\
\hline Temperature & 0.001 & $<0.001$ & 0.151 & 0.066 & 0.002 & 0.002 & 0.477 & $<0.001$ & 0.540 \\
\hline Interaction & 0.058 & 0.018 & 0.005 & 0.400 & 0.038 & 0.078 & 0.324 & 0.050 & 0.354 \\
\hline
\end{tabular}

Means in the same column with different letter are significantly different $(p<0.05)$.

Egg quality of two eggs were measured per cage $(n=2)$.

EW: egg weight, EST: eggshell thickness, ESS: eggshell strength, YC: yolk color, HU: Haugh unit, AH: albumen height, YW: yolk weight, AW: albumen weight, ESW: eggshell weight, kgf: kilogram force.

Units: EW, YW, AW and ESW: g, EST: mm, ESS: kgf. 
heat stress, the levels of oxidative products increases in the whole body and in the reproductive system of laying birds. High levels of oxidative products in body of laying hens could increase level of oxidative products in eggs. In addition, there are studies (Bottje \& Harrison, 1985; Teeter et al., 1985) that showed that, under heat stress conditions, the calcification of eggshell is poor and egg internal quality may be affected. Poor calcification exposes the internal material of eggs to oxygen and especially after long storage times, oxidative deterioration accelerated.

A comprehensive consideration of the data and the results presented in this study showed that performance parameters, such as body weight, feed intake, and egg production, experienced little influence of fennel consumption by the hens; however, egg quality was significantly affected by fennel inclusion in the diet. In general, the use of medicinal plants in animal and poultry nutrition is more related with the quality of products and the health of consumers than with the quantity of products.
Heat stress at first affects the appetite of birds, significantly reducing their feed intake, and may consequently affect other productive parameters of laying hens (Mahmoud et al., 1996; Balnave and Muheereza, 1997; Balnave \& Broke 2005). In the present study, the feed intake of hens submitted to heat stress was significantly reduced and therefore other parameters, like egg weight, albumen weight, and eggshell thickness were affected by the low feed intake. Although the dietary inclusion of fennel did not affect feed intake, most of the negative effects of heat stress on egg quality parameters were alleviated when hens consumed 10 or $20 \mathrm{~g}$ of fennel $/ \mathrm{kg}$ of diet.

After one month hens started to be fed fennel, all birds presented a reduction in egg production. This reduction was smaller in the birds that received fennel in their diet, but there was no difference among treatments. Some factors might have induced this reduction, such as natural reduction of egg production after the peak and the stress of handling the birds for body weight measurement and allocation of birds

Table 4 - Mean value of total cholesterol and Triglycerides contents and lipid and protein oxidation of egg before and after heat stress.

\begin{tabular}{|c|c|c|c|c|c|}
\hline & Treat & Total cholesterol a & Triglycerides a & $\mathrm{MDA}^{\mathrm{b}}$ & Carbonyl $^{c}$ \\
\hline \multicolumn{6}{|c|}{ Fennel level (g/kg diet) } \\
\hline \multirow{7}{*}{ 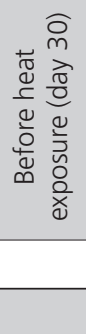 } & 0 & $13.78^{x}$ & $225.20^{x}$ & 52.42 & 4.32 \\
\hline & 10 & $10.38^{y}$ & $195.80^{y}$ & 47.71 & 4.41 \\
\hline & 20 & $10.12^{y}$ & $194.40^{y}$ & 50.55 & 4.39 \\
\hline & SE & 0.48 & 3.96 & 1.72 & 0.03 \\
\hline & CV & 16.34 & 7.49 & 13.23 & 2.77 \\
\hline & $p$-value & $<.0001$ & $<.0001$ & 0.5627 & 0.4657 \\
\hline & \multicolumn{5}{|l|}{ Temperature } \\
\hline \multirow{8}{*}{ 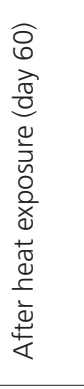 } & $24^{\circ} \mathrm{C}$ & 11.42 & $205.13^{a}$ & $50.22^{b}$ & $4.37^{b}$ \\
\hline & $34^{\circ} \mathrm{C}$ & 11.13 & $196.60^{b}$ & $95.48^{a}$ & $5.68^{a}$ \\
\hline & \multicolumn{2}{|c|}{ Fennel level (g/kg diet) } & & & \\
\hline & 0 & $13.81^{x}$ & $217.00^{x}$ & $82.16^{x}$ & $5.22^{x}$ \\
\hline & 10 & $10.31^{y}$ & $193.60^{y}$ & $71.24^{y}$ & $5.02^{y}$ \\
\hline & 20 & $9.71^{y}$ & $192.00^{y}$ & $65.15^{y}$ & $4.83^{z}$ \\
\hline & SE & 0.36 & 2.52 & 4.73 & 0.13 \\
\hline & $\mathrm{CV}$ & 17.48 & 6.86 & 25.58 & 14.53 \\
\hline \multicolumn{6}{|c|}{$p$-value } \\
\hline & Fennel & $<.0001$ & $<.0001$ & $<.0001$ & 0.0008 \\
\hline & Temperature & 0.2951 & $<.0001$ & $<.0001$ & $<.0001$ \\
\hline & Interaction & 0.4177 & 0.0136 & 0.0003 & 0.0001 \\
\hline
\end{tabular}

Means in the same column (in each part of table) with different letter are significantly different $(p<0.05)$.

Cholesterol, Triglyceride, MDA and carbonyl were measured in two eggs per cage $(n=2)$.

${ }^{a}$ Cholesterol and triglyceride values expressed as milligrams per gram of yolk.

${ }^{\mathrm{b}}$ TBA values expressed as nanograms of malondialdehyde (MDA) per gram of egg (fresh egg).

'Unit of protein carbonyl content: nanomoles of 2, 4-dinitrophenylhydrazine per gram of protein. 
Table 5 - Parameters significantly had interaction between temperature and fennel in day 60

\begin{tabular}{|c|c|c|c|c|c|c|c|}
\hline Treat & . & $24^{\circ} \mathrm{C}$ & - & - & $34^{\circ} \mathrm{C}$ & - & $p$-value \\
\hline & $0 \mathrm{~g} / \mathrm{kg}$ Fen. & $10 \mathrm{~g} / \mathrm{kg}$ Fen. & 20 g/kg Fen. & $0 \mathrm{~g} / \mathrm{kg}$ Fen. & 10 g/kg Fen. & 20 g/kg Fen. & \\
\hline BEP d28 & $2.85^{y}$ & $3.33^{y}$ & $3.08^{y}$ & $25.02^{x}$ & $11.28^{y}$ & $7.64^{y}$ & 0.047 \\
\hline EST $(\mathrm{mm})$ & $0.29^{x}$ & $0.29^{x}$ & $0.30^{x}$ & $0.22^{y}$ & $0.27^{x}$ & $0.28^{x}$ & 0.018 \\
\hline ESS (kgf) & $2.73^{x}$ & $2.73^{x}$ & $2.52^{x}$ & $1.90^{y}$ & $2.58^{x}$ & $2.91^{x}$ & 0.005 \\
\hline $\mathrm{HU}$ & $86.20^{\mathrm{a}}$ & $83.22^{\mathrm{a}}$ & $87.36^{a}$ & $72.96^{b}$ & $82.24^{\mathrm{a}}$ & $81.80^{\mathrm{a}}$ & 0.038 \\
\hline Triglycerides a & $225.20^{x}$ & $195.80^{z}$ & $194.40^{z}$ & $208.80^{y}$ & $191.40^{z}$ & $189.60^{z}$ & 0.0136 \\
\hline $\mathrm{MDA}^{\mathrm{b}}$ & $52.41^{z}$ & $47.69^{2}$ & $50.55^{z}$ & $111.90^{w}$ & $94.78^{x}$ & $79.77^{y}$ & 0.0003 \\
\hline Carbonyl c & $4.32^{z}$ & $4.41^{z}$ & $4.39^{z}$ & $6.13^{w}$ & $5.63^{x}$ & $5.27 y$ & 0.0001 \\
\hline
\end{tabular}

Means in the same row with different letter are significantly different $(p<0.05)$.

Measurements were taken in two eggs per cage $(n=2)$.

a Triglyceride values expressed as milligrams per gram of yolk.

${ }^{\text {' TBA }}$ values expressed as nanograms of malondialdehyde (MDA) per gram of egg (fresh egg).

'Unit of protein carbonyl content: nanomoles of 2, 4-dinitrophenylhydrazine per gram of protein.

to different treatments. Regardless of the reasons of this reduction, there were no differences among the experimental treatments.

The other productive parameter that was affected by heat stress was number of broken eggs. Heat stress did not affect the number of eggs produced, but because of low feed intake and poor calcification, eggshell thickness and strength were reduced, and consequently the number of broken eggs increased. This phenomenon was also reported by Mashaly et al. (2004). According to results obtained in the present study, the consumption of fennel could alleviate most of the negative effects of heat stress on the production of broken eggs. This is related to the reduction of the amount of oxidative products present in reproductive organs and its effect on eggshell calcification. A similar result was reported by Sahin et al. (2011).

Another interesting result obtained in this experiment was relative to cholesterol and triglyceride yolk levels. Data showed fennel consumption significantly reduced cholesterol and triglyceride levels in the eggs, independently of heat stress. Despite the significant interaction between temperature and fennel consumption for triglyceride yolk content, in absence of heat stress, the beneficial effect of fennel consumption on yolk cholesterol and triglyceride content was evident. Some studies reported the effect of medicinal plants and their extracts on egg cholesterol and triglyceride levels (Akhtar et al., 2003; Aydin et al., 2008). The effect of medicinal plants on egg cholesterol and triglyceride level is ascribed to their active components. The main active component in fennel fruit is anethole, which is a phytosterol itself (Badoc et al., 1994; Piccaglia and Marotti, 2001; Damianova et al., 2004). Anethole, like other plant sterols, alters metabolic pathways in the body of laying hens, leading to cholesterol and triglyceride reduction. In a recent study with rats, the application of anethole derived from fennel improved blood levels of total cholesterol, LDL, HDL, and triglycerides (Dongare et al., 2012). This study could explain the effect of fennel on yolk cholesterol and triglyceride contents obtained in the present study and also confirm the relationship between anethole and changes in the lipid profile of eggs.

Before heat exposure, when laying hens only received the fennel treatment, there were no significant changes in amount of oxidative products in the eggs. After heat stress treatment was applied, the amount of oxidative products (MDA and carbonyl) significantly increased in the eggs produced under high temperature. This increase in the levels of oxidative products is directly related to high temperature and to the production of free radicals and changes in metabolic pathways when hens are submitted to heat stress. Fennel contains antioxidant substrates (Oktay et al., 2003) like anethole that could alleviate these adverse effects of heat stress in some extent.

\section{CONCLUSION}

According to this study, under normal conditions (ambient temperature), the inclusion of fennel fruit in laying hen diets had no clear effect on performance, egg production, or egg quality. However, under heat stress conditions, when amount of oxidative products are high, the consumption of fennel fruit as a natural antioxidant may reduce harmful effects of free radicals in laying hens. Independently of heat stress, the consumption of fennel significantly reduced the amount of cholesterol and triglycerides in the egg yolk. 
Due to its antioxidant activity and its beneficial effect on yolk cholesterol and triglyceride levels, fennel may be a good candidate as a feed additive in poultry nutrition.

\section{REFERENCES}

Akhtar MS, Nasir Z, Abid AR. Effect of feeding powdered Nigella sativa L. seeds on poultry egg production and suitability for human consumption. Veterinarski Arhiv 2003;73:181-190

Asli MM, Hosseini SA, Lotfollahian H, Shariatmadari F. Effect of probiotics, yeast, vitamin $\mathrm{E}$ and vitamin $\mathrm{C}$ supplements on performance and immune response of laying hens during high environmental temperature. International Journal of Poultry Science 2007;6:895-900.

Aydin R, Karaman M, Cicek T, Yardibi H. Black Cumin (Nigella Sativa L) suplementation into the diet of the laying hen positively influences egg yield parameters, shell quality, and decreases egg cholesterol. Poultry Science 2008:87:2590-2595.

Badoc A, Deffieux G, Lamarti A, Bourgeois G, Carde JP. Essential oil of Foeniculumvulgare Mill. (Fennel) subsp. Piperitum (Ucria) Cout.fruit. Journal of Essential Oil Research 1994;6:333-336

Balnave D, Muheereza SK. Improving eggshell quality at high temperatures with dietary sodium bicarbonate. Poultry Science 1997;76:558-593.

Balnave D, Brake G. Nutrition and management of heat-stressed pullets and laying hens. World's Poultry Science Journal 2005;61:399-406.

Barazani O, Fait A, Cohen Y, Diminshtein S, Ravid U, Putievsky E, et al. Chemical variation among indigenous populations of Foeniculum vulgare var. vulgare in Israel. Planta Medica 1999;65:486-489.

Boehringer Mannheim GmbH. Methods of biochemical analysis and food analysis. Mannheim: Boehringer; 1989. p.26-28.

Botsoglou NA, Fletouris DJ, Papageorgiou GE, Vassilopoulos VN, Mantis AJ, Trakatellis AG. Rapid, sensitive, and specific thiobarbituric acid method for measuring lipid peroxidation in animal tissue, food and feedstuff samples. Journal of Agricultural and Food Chemistry 1994;42:19311937.

Damianova S, Stoyanova A, Konakchiev A, Djurdjev I. Supercritical carbon dioxide extracts of spices. 2. Fennel (Foeniculumvulgare Mill. Var. Dulce Mill.). Journal of Essential Oil Bearing Plants 2004;7:247- 249.

Damianova S, Stoyanova A, Konakchiev A, Djurdjev I. Inhibition of aldose reductase and anti-cataract action of trans-anethole isolated from Foeniculum vulgare Mill. fruits. Food Chemistry 2004;132:385-390.

Elkin RG. Reducing shell egg cholesterol content. II. Review of approaches utilizing non-nutritive dietary factors or pharmacological agents and an examination of emerging strategies. World's Poultry Science Journal 2007;63:5-32

Er D, Wang Z, Cao J, Chen Y. Effect of monochromatic light on the egg quality of laying hens. Journal of Applied Poultry Research 2007:16:605-612.

Galobart J, Barroeta AC, Baucells MD, Codony R, Ternes W. Effect of dietary supplementation with rosemary extract and $\alpha$-tocopheryl acetate on lipid oxidation in eggs enriched with T3-fattyacids. Poultry Science 2001;80:460-467.

Guilled MD, Manzanons MJ. A study of several parts the plant Foeniculum vulgare as a source of compounds with industrial interests. Food Research International 1996;29:85-88.

Gousi RM, Morris TM. Nutritional interventions in alleviating the effects of high temperatures in broiler production. World's Poultry Science Journal 2005;61(3):463-475
Hammad SM, Siegel HS, Marks HL. Dietary cholesterol effects on plasma and yolk cholesterol fractions in selected lines of Japanese quail. Poultry Science 1996;75:933-942.

Kaya S, Keçeci T, Haliloğlu S. Effects of zinc and vitamin A supplements on plasma levels of thyroid hormones, cholesterol, glucose and egg yolk cholesterol of laying hens. Research in Veterinary Science 2001:71:135-139.

Liu B, Li W, Chang Y, Dong W, Ni L. Extraction of berberine from rhizome of Coptischinensis Franch using supercritical fluid extraction. Journal of Pharmaceutical and Biomedical Analysis 2006;41:1056-1060.

Lopez-Bote CJ, Gray Jl, Gomaa EA, Flegal CJ. Effect of dietary administration of oil extracts from rosemary and sage on lipid oxidation in broiler meat. British Poultry Science 1998;39:235-240.

Mahmoud KZ, Beck MM, Scheideler SE, Forman MF, Anderson KP, Kachman SD. Acute high environmental temperature and calcium-estrogen relationship in the hen. Poultry Science 1996;75:1555-1562.

Mashaly MM, Hendricks GL, Kalama MA, Gehad AE, Abbas AO, Patterson $\mathrm{PH}$. Effect of heat stress on production parameters and immune responses of commercial laying hens. Poultry Science 2004;83:889894.

Mercier Y, Gatellier P, Vincent A, Renerre M. Lipid and protein oxidation in microsomal fraction from turkeys: Influence of dietary fat and vitamin E supplementation. Meat Science 2001;58:124-134.

Odom TW, Harrison PC, Bottje WG. Effects of thermal-induced respiratory alkalosis on blood ionized calcium levels in the domestic hen. Poultry Science 1986;65:570-573.

Oguntunji OT, Alabi OM. Influence of high environmental temperature on egg production and shell quality: a review World's Poultry Science Journal 2010;66:739-752.

Oktay M, Gülçin I. Küfrevioglu I. Determination of in vitro antioxidant activity of fennel (Foeniculum vulgare) seed extracts. LebensmittelWissenschaft and Technologie 2003;36:263-271.

Ozbek H, Ugras S, Dulger H, Bayram I, Tuncer I, Ozturk G, et al. Hepatoprotective effect of Foeniculum vulgare essential oil. Fitoterapia 2003;74:317-319.

Park SJ, Yoo SO. Effects of supplementation of Chinese medicine refuse on performance and physiology in broiler chicks. Korean Journal of Poultry Science 1999;26:195-201.

Piccaglia R, Marotti M. Characterization of some Italian types of wild fennel (Foeniculum vulgare Mill). Journal of Agricultural and Food Chemistry 2001;49:239-244.

Ruberto G, Baratta MT, Deans SG, Dorman HJ. Antioxidant and antimicrobial activity of Foeniculum vulgare and Crithmum maritimum essential oils. Planta Medica 2000;66(8):687-693.

SAS. SAS/STAT user's guide. Released 9.1 Cary, NC: SAS Institute; 2001.

Sahin K, Orhan C, Akdemir F, Tuzvh T, Ali S, Sahin N. Tomato powder supplementation activates Nrf-2 via ERK/Akt signaling pathway and attenuates heat stress-related responses in quails. Animal Feed Science and Technology 2011;65:230-237.

Sahin K, Orhan C, Smith M, Sahin N. Molecular targets of dietary phytochemicals for the alleviation of heat stress in poultry. World Poultry Science Journal 2013;69:113-124.

Simitzis PE, Deligeorgis SG, Bizelis JA, Dardamani A, Theodosiou I, Fegeros $K$. Effect of dietary oregano oil supplementation on lamb meat characteristics. Meat Science 2008;79:217-223. 
Van Den Brand H, Parmentier HK, Kemp B. Effects of housing system (outdoor vs. cages) and age of laying hens on egg characteristics. British Poultry Science 2004;45:745-752.

Vichi S, Zitterl-Eglseer $\mathrm{K}$, Jugl M, Franz $\mathrm{CH}$. Determination of the presence of antioxidants deriving from sage and oregano extracts added to animal fat by means of assessment of the radical scavenging capacity by photochemiluminescence analysis. Nahrung/ Food 2001;45:101-104.
Yahav H. Alleviating heat stress in domestic fowl: different strategies. World's Poultry Science Journal 2009;65:719-732.

Wood JD, Enser M. Factors influencing fatty acids in meat and the role of antioxidants in improving meat quality. British Journal of Nutrition 1997;78:\$49-S60

Yaylayan VA. Flavour technology: recent trends and future perspectives. Canadian Institute of Food Science and Technology Journal 1991;24:2-5. 
